\title{
ВАС НЕ ЛЯКАЄ СУД ІСТОРЇ,, ПАНОВЕ?
}

\author{
Наталія Мазепа
}

Доктор філологічних наук, Київ (УКРАїНА)

\section{PЕФЕРАТ}

Стаття присвячена актуальній проблемі протидії знищенню історичного архітектурного обличчя столиці України міста Києва сучасними забудовниками.

Ключові слова: Київ, культурна пам'ять, сучасний вандалізм.

\section{AREN'T YOU SCARED BY THE COURT OF HISTORY, GENTLEMEN?}

\author{
Nataliia Mazepa \\ Doctor of Philological Sciences, \\ Kyiv (UKRAINA)
}

\begin{abstract}
The article is devoted to the topical issue of counteracting the destruction of the historical architectural face of the capital of Ukraine, the city of Kyiv by modern developers.

Key words: Kyiv, cultural memory, modern vandalism.

Не знаю, коли знайдеться український історик, котрий відверто і чесно напише про те, як і хто зруйнував старовинне, колись надзвичайно гарне місто Київ. Той, невідомий сьогодні історик, змушений буде розказати не лише про руйнування Київських святинь за часів радянської влади, а й про те, що тотальне руйнування старовинного Києва відбувалося за часів президента Л. Кучми і президента В. Ющенка, прем'єр-міністра В. Януковича і прем'єр-міністра Ю. Тимошенко. І всі вони за це варварське руйнування відповідають перед історією. Бо ніхто з них цей злочин не зупинив. Не зміг, або не схотів.

Існує відомий вислів: «Священні камені Свропи». Священні тому, що зберігають Пам'ять про життя народу, про його історію. Саме в цій пам'яті закладені витоки культури, iї архетипи. Київ, природньо, мав свої традиції, свою, дуже складну й драматичну історію, як і вся наша країна. Київ був справжнім європейським містом: історія багатьох віків відбита, вкарбована в камені його будівель, церков, житлових будинків, палаців, невеличких кам'яниць.

Культурологи і мистецтвознавці іноді зауважували, що київська архітектура еклектична, адже у ній відсутній панівний стиль. Докір якоюсь мірою справедливий. Але не цілком. Київ, яким він був іще у 80-і роки минулого століття, забудовувався переважно наприкінці XIX - на початку XX ст. у стилі тогочасного модерну. Від українського бароко він перейняв схильність до прикрас, до вишуканості, а все інше - то була так звана «фонова забудова», житлові «нейтральні» будинки, котрі підкреслювали яскравість основних будівель.
\end{abstract}


Найпомітнішою рисою Києва був його рельєф (пагорби), а також наше зелене багатство: розкішні сади, сквери, дерева у кожному дворі та вздовж вулиць. Старовинна споруда на зеленому пагорбі - саме це створювало типовонеповторний київський пейзаж. Побутувала думка, що в цілому світі $є$ три міста на пагорбах: Єрусалим, Рим і Київ.

Цього Києва більше не існує. Хоч як це прикро, його знищено у 90-ті роки минулого століття, і цей злочинний процес триває зараз. Хмарочоси в центрі міста нівелювали унікальний рельєф. Вони затиснули, закрили наші пагорби. 3 будь-якої високої точки за межами центру можна побачити тільки хмарочоси. Хаотично розкидані, вони домінують над усім. Не згадуватимемо про їхню «естетичну» якість. Це вже не європейський пейзаж, а типове місто третього світу. В Європі, приміром, побудували цілком новітній Дефанс, але за межами старого Парижа. Із Градчан у Празі, звідки видно старе місто, ви не побачите жодної новітньої споруди. Ось це і є повага до історії, до традиції, до самих себе. Ми ж поводимося у столиці власної держави, немов варвари в чужій країні. I не треба стверджувати, що божевільне будівництво проводиться заради киян. Жоден пересічний український громадянин купити квартиру в історичному центрі міста не може. Це аксіома. Це відомо всім. Для кого ж ці хмарочоси, що їх інакше, ніж «монстрами», жоден киянин не називає? Для кого ці нібито житлові будинки, «офісні центри», оте все, що руйнувало наше місто і далі руйнує? Хто вони? Відомо, що започаткував все це мер О. Омельченко. Продовжує теперішній очільник. Коли кияни побачили прізвище Омельченка в списках НУНС, ця політична сила втратила голоси багатьох киян. Але чому ніхто не зупинить безумство?

Важко уявити поруч із паризькою Гранд Опера або Ковент-Гарденом у Лондоні колосальну страшну споруду, саме таку, котра знищує наш Оперний театр і всі старовинні, дивом уцілілі будинки навколо. А уявляєте Нотр-Дам, а впритул до нього підступило щось блакитне й рожеве, важке, без форми, без пластики, - саме той жах, що оточив нашу Святу Софію? I ніхто не зупинив, не заборонив, не притягнув до суду «будівельників» та їхніх можновладних покровителів.

Кияни відчайдушно відстоюють кожен клаптик київської землі: свої дворики, дитячі й спортивні майданчики, сквери, сади, старовинні будинки, звідки їх викидають, адже будинки приречені на знищення. Справжні кияни - це ті, котрим дороге місто, котрі його знають, розуміють і цінують, незалежно від того, де вони народилися і жили раніше, або де мешкають тепер, - на Троєщині чи Борщагівці, на Позняках чи Нивках. I треба визнати - немає лідера, котрий би зібрав їх усіх, об’єднав у протестному русі...

От і гине прекрасне, колись романтичне, затишне, створене для нормального життя місто...

А тепер про речі суто практичні. Київ розташований не тільки на пагорбах: під ним протікають майже 300 маленьких річок і струмків. Коли місто розбудовували, всі вони у різний час були замкнені в колектори. Більша частина колекторів, як і всі підземні комунікації міста, застарілі. Це завжди створювало додаткові труднощі під час прокладання метро. Люди звертають увагу і 
на те, що час від часу на стінах окремих станцій метро з'являються водяні плями. Крім того, під Києвом існує величезна кількість печер, підземних ходів і приміщень. Нещодавно «П'ятий канал» показував підземні переходи і «приміщення» просто під Маріїнським парком i Маріїнським палацом. Внаслідок таких підземних особливостей, київський грунт є дуже специфічним: він легко обвалюється, він рухомий, він вимагає обережного і уважного ставлення. Величезна фігура жінки з мечем над Дніпром стоїть на суцільному бетоні, а колись там існував пагорб. Коли цю статую будували, пагорб просто розвалився. Відомо, що в центрі міста дедалі більше старовинних і радянських споруд стають аварійними, - це також наслідки будування хмарочосів, які здебільшого є бетонними. Київський грунт не витримує навантаження стількох тон бетону. I схоже, ніхто не аналізує і не прораховує ситуацію в центрі Києва. I ніхто не збирається проводити серйозні геологічні експертизи. I медичні, до речі, також. Хоча відомо, що кількість авто на вулицях Києва і постійні «корки» вже зумовили появу у повітрі неприпустимої кількості канцерогенів (речовин, що викликають злоякісні пухлини). Розв’язати ситуацію на вузьких вулицях старого міста практично неможливо. I чому нам, пересічним киянам, було цілком очевидно, що нерозумне будівництво в старому місті спричинить транспортний колапс, а мер і усі можновладці цього не розуміли? Чи просто вони живуть за сумнозвісним принципом «після мене хоч потоп»?

Зараз уже виправити нічого не можна. Але слід запобігти катастрофі там, де вона наближається.

1. Не можна допустити будівництва на Володимирській гірці. А воно, як мені відомо, вже заплановане. Мабуть, усі помічають, що за Українським Домом знаходиться невеличкий майданчик. Там не росте жодне дерево. I не може рости, бо майданчик - це тільки прикритий грунтом суцільний бетон. Історія його появи така. Початок будівництва Українського Дому (тоді музею Леніна) супроводжувалося вирубуванням певної кількості дерев. Цього виявилося достатньо, щоб грунт почав рухатися, розпадатися. Всю ту місцину залили бетоном, а зверху насипали землю. А тепер уявіть, що може початися на Володимирській гірці, коли туди прийде важка будівельна техніка, коли знесуть старовинні будинки (невеликі, цегляні, а тому легкі), і коли почнуть копати величезний котлован, заливаючи все тоннами бетону... Що може статися із нашою Гіркою, із пам’ятником Святому Володимирові, з алеями. Не виключено, що будівництво становитиме загрозу Олександрівському костьолу, Костьольній вулиці. А там ще залишилося кілька старовинних, надзвичайно цікавих будинків. А головне: той, хто піднімає руку на Володимирську Гірку, чинить святотатство. Це комусь незрозуміло? Якщо навіть припустити, що загроза малоймовірна, але таки існує, яка потреба в такому ризику? Тільки для того, щоб «інвестор» цинічного проекту вкотре заробив шалені гроші. На цей раз ціна завелика.

2. Не можна допустити будівництв під пагорбом Андріївського собору, навіть якщо там планується музей насправді видатного художника I. Марчука. Андріївський собор більше десяти років перебував на капітальному ремонті не тому, що цього потребувала сама споруда, а тому, що аварійним є пагорб. До нього з будівельною технікою навіть наближатися не можна. 3 тієї ж причини 
не можна будувати Десятинну церкву. Не кажучи про те, що Володимирська вулиця перенасичена копіями та підробками.

3. Треба вже зараз рятувати Святу Софію, яка перебуває в облозі автомашин (подумати лишень: підземний паркінг!) За все моє довге життя я бачила лише одного культурного мера столиці, Володимира Гусєва, який заборонив навіть наближатися до Софії автобусам із туристами і скоротив потік машин (а ïх було колись незрівнянно менше!). Найстаріші фрески, розташовані внизу Софії, майже біля підлоги (виїзд князя, полювання), поступово зникають через гарячі викиди машин. Цей процес дуже скоро може стати незворотнім. Так стверджують фахівці-реставратори. Із цієї ж причини не варто запалювати в Храмі свічки, хоча тепер це роблять постійно (як і бенкети на Софійському подвір'ї, що обурює вірян і про що наш Президент, мабуть, і не знає). Треба провести незалежну експертизу землі всього Софійського подвір'я. Нікому невідомо, що там відбувається після того як поруч, у дворі на розі Софійського майдану і Рильського провулку, побудували щось, що перекрило струмок під подвір'ям. У будинку тепер мешкають пани з охороною, а доступу в той двір немає. Ситуацію погіршує і вирубування старих дерев навколо Храму.

4. Не вірю, на жаль, що існує можливість врятувати Києво-Печерську лавру. Біда там почалася дуже давно, ще коли Хрущов наказав закрити і засипати колодязі зі святою водою. Вже тоді підземний рух почався. Будівництво Успенського собору за допомогою сучасних методів і техніки, а також шалене будівництво хмарочосів по всьому Печерську над Лаврою, зробило ситуацію безнадійною. Однак намагатися щось зробити треба. Щоправда, зараз уже ніхто не знає, що саме.

5. Величезну тривогу викликає так звана реконструкція Андріївського узвозу. Насправді реконструкція по-київськи означає знищення. Якщо старовинні будинки «реконструйовують», їх уже ніхто не впізнає. Андріївський узвіз можна лише ремонтувати, консервувати. I повністю віддати музейникам, художникам і акторам. (Крім кількох дивом уцілілих житлових будинків). Досі стоїть, наче нікому непотрібний і буцімто реставрований «Замок Річарда». Йому слід було б повернути його балкончики і тераси, сходи і сходинки (i безумовно, знести побудовану поруч невідомо для чого бридку бетонку). На першому поверсі відкрити найбільший магазин в Києві «Українська книга» із виставковим центром і конференц-залом. Туди гарантовано приходитиме багато людей. Всі інші поверхи слід віддати художникам і галеристам. I хоч як було б противно панові голові Шевченківського району - головному ворогові художників і галеристів, акторів і музикантів, - потрібно у Києві на законодавчому рівні передати всім художникам їхні майстерні у довічне володіння. Так було зроблено в Парижі. I так діє мер Львова А. Садовий. Інтелігентний мер культурного міста. Художники платять за це мерії своїми творами (25\% умовної ціни майстерні). Завдяки цьому, між іншим, мерія зі стандартної «контори» перетворюється на дуже привабливе, гарне приміщення. Може, аура мистецьких творів почне впливати і на нашу міську раду? (Розумію, що останнє схоже радше на жарт). 
6. Нагальним є чіткий, усім зрозумілий план відродження міста. Зараз у центрі, крім дорогих бутиків, «точок» із продажу мобілок і пива, нічого побачити неможливо. У такий план потрібно включити відкриття музею I. Франка. Останній будинок, де він жив і де ще дивом зберігається меморіальна дошка, знаходиться у Кудрявському провулку, за квартал від Будинку художника на Львівський площі. Він у жахливому стані i, схоже, тут діє перевірена роками тактика київської влади: довести старовинний будинок до аварійного стану і на цій підставі знищити.

Дописала цей наболілий текст і подумала: до кого я звертаюся? Кого я сподіваюся переконати? Мабуть, такої людини я не знаю. Тому і питаю:

- ПАНОВЕ, ВИ НЕ БОЇТЕСЯ СУДУ ІСТОРІї ЗА РУЙНУВАННЯ СТОЛИЦІ СВОСЇ КРАЇНИ? ح2008-2010 роки

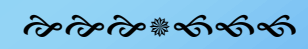

